\title{
Water Quality Restoration of a Drinking Water Outlet Area in a Eutrophic Reservoir Using Hypolimnetic Oxygenation in Southwest China
}

\author{
Chen Lan ${ }^{1 *}$, Yongxue Ji ${ }^{1}$, Jingfu Wang², Haiquan Yang² \\ ${ }^{1}$ School of Management Science and Engineering, Guizhou University of Finance and Economics, \\ Guiyang 550025, China \\ ${ }^{2}$ State Key Laboratory of Environmental Geochemistry, Institute of Geochemistry, Chinese Academy of Sciences, \\ Guiyang 550002, China
}

Received: 11 April 2020

Accepted: 29 June 2020

\begin{abstract}
The aquatic environments of the world are facing the severe challenge of eutrophication. Lakes and reservoirs that are regarded as drinking water sources are particularly in danger. Once the water quality deteriorates, serious impacts will occur on the subsequent water supply and drinking water safety. This study focuses on the Aha Reservoir, a sub-deep eutrophic reservoir in Southwest China polluted by phosphorus. This site was selected because it is currently undergoing aquatic restoration. It will be the first to use bubble plume diffusers at the drinking water outlet area where water is removed from the reservoir to provide drinking water to the community, to enhance water quality. There was a significant decrease in total phosphorus (TP) and total nitrogen (TN) concentrations in the experimental zone (0.04-0.02 $\mathrm{mg} / \mathrm{L}$ and $1.9-1.7 \mathrm{mg} / \mathrm{L}$, respectively), with no significant decrease in TP and TN concentrations at the control sites. Compared with the control sites, concentrations of $\mathrm{NH}_{4}^{+}$, total Fe, and total Mn were reduced by $15.5 \%, 45.5 \%$, and $48.9 \%$, respectively. In addition, the application of this technique had a significant influence on the evolution of algal phytoplankton in the eutrophic reservoir. The number of cyanobacteria species in the drinking water outlet area decreased by $33-100 \%$ during the peak period of algal blooms, with no sign of an increase at all. Moreover, the number of phytoplankton species at the experimental site decreased by as much as $82.6 \%$ compared with the corresponding period prior to application. Hypolimnetic oxygenation displayed great effectiveness for aquatic restoration in this eutrophic water system.
\end{abstract}

Keywords: eutrophication, hypolimnetic oxygenation, water intake, bubble plume diffusers, water environment restoration

*e-mail: lanchen999@126.com 


\section{Introduction}

Lake and reservoir eutrophication is one of the most important problems facing aquatic environments of the world [1,2]. With the continued acceleration of industrialization and urbanization, the eutrophication degrees of the lakes and reservoirs are increasingly aggravated. This leads to a decline in the adjustment function of lakes and reservoirs and an imbalance in water ecosystems [2-5]. The current status of this issue indicates that eutrophication seriously affects the health of aquatic environments worldwide. The YunnanKweichow plateau is a concentrated area of fresh water lakes and reservoirs in China that includes numerous sub-deep reservoirs [6, 7]. These reservoirs are located in an area that has a carbonate geological background with a weak purification capacity for pollutants and a small environmental capacity [8-10]. Due to longterm unreasonable development, utilization of water resources in the past, and a lack of awareness of protection and management, many sub-deep reservoirs in the Yunnan-Kweichow plateau are facing serious eutrophication problems. This directly threatens the regional water supply and ecological environmental security [11-13]. China has a large number of sub-deep reservoirs, each with an average depth of 10-30 m [6, 7]. Sub-deep reservoirs are difficult to restore once polluted by excessive phosphorus because they are too deep to be protected by macrophytes in their littoral zones and too shallow to mitigate phosphorus recycling through hypolimnetic dilution [14].

To date, the aquatic environment has been deteriorating continuously. The research and development of the technology of water treatment and water environment remediation has been ongoing for solving the problem of water safety and health [1520]. Reaeration is comprised of three main categories: water-mixing, hypolimnetic aeration, and hypolimnetic oxygenation [21]. Among these, hypolimnetic oxygenation has received great attention for its higher restorative efficiency and fewer adverse effects [22, 23]. Bubble plume diffusers, one of the most popular technologies for hypolimnetic oxygenation, have been successfully operated in several water systems [24, 25]. However, they have never been operated to test the influence on the water quality environment near a drinking water outlet area in a eutrophic reservoir. Once a reservoir is regarded as a source of drinking water, its water body is usually pumped into the steel pipes via a water pump at the drinking water outlet area. Then the water subsequently flows into municipal waterworks $[26,27]$. Due to the particularity of the geographical location and function of a drinking water supply outlet area, it is difficult to plant any ecological restoration plants near these areas, even in a reservoir suffering from severe eutrophication $[8,28,29]$. The water quality environment in this drinking water outlet area is very fragile $[26-28,30]$. Once an algal bloom outbreak occurs, if there have been no measures to reduce the algae in the water outlet area, this will lead to an increase in the amount of chemical used in the water supply to purify it and an increase in the cost of water production $[31,32]$. Water quality will obviously be severely affected $[33,34]$. Therefore, water quality restoration near the drinking water outlet area of a eutrophic reservoir is critical [27, 30,35].

In this study, the Aha Reservoir, a typical eutrophic drinking water system in southwest China, was selected to conduct a field experiment to test the influence of hypolimnetic oxygenation on the water environment near the drinking water outlet area in a eutrophic reservoir. Therefore, this study can provide basic data and scientific guidance for eutrophication prevention and control of water outlet areas related to drinking water sources. The aims of this study are as follows: (1) to test the effectiveness of hypolimnetic oxygenation for the restoration of water quality near a water outlet area; (2) to explore the influence of bubble plume diffusers on phytoplankton evolution near a water outlet area; and (3) to provide a case study for reference.

\section{Materials and Methods}

\section{Research and Analytical Protocol}

The Aha Reservoir (AHR) (E106 $37^{\prime}-106^{\circ} 39^{\prime}$, $\mathrm{N} 26^{\circ} 30^{\prime}-26^{\circ} 33^{\prime}$ ) was built in 1960 . It is located in the southern suburb of Guiyang city and belongs to the Wujiang River system. The reservoir has a watershed area of $190 \mathrm{~km}^{2}$, with a total volume of $4.45 \times 10^{7} \mathrm{~m}^{3}$ at the normal water level of $1108 \mathrm{~m}$ [6]. Its primary function is urban water supply and flood control. The AHR was formed by the confluence of five tributaries, has an average depth of $13 \mathrm{~m}$, and a maximum depth of $30 \mathrm{~m}$. The ZC water intake is located next to the dam. As shown in Fig. 1, the ZC drinking water outlet area in the AHR was selected as the research area to conduct the aquatic environment restoration experiment. Two representative sites, $\mathrm{A}$ and $\mathrm{B}$, were selected as the control sites. A was located closer to the research area, and B was further away. In addition, the location of the reaeration device was selected as the in situ site. The water column is typically thermally stratified from late June to September [13]. Water quality and algae samples were collected and analyzed from March 2016 to July 2017. The water quality analysis indexes include total phosphorus (TP), total nitrogen (TN), soluble phosphate $\left(\mathrm{PO}_{4}^{3-}\right)$, transparency (SD), water temperature (T), dissolved oxygen (DO), $\mathrm{pH}$ and electrical conductivity (EC). Water quality samples with a volume of $1.5 \mathrm{~L}$ were collected to quantify the phytoplankton. The samples were fixed with Luger's reagent and returned to the laboratory to stand and concentrate. The algal species were then identified, and their abundances were calculated.

To understand the water quality characteristics in the drinking water outlet area, water samples were collected in July, August, and September 2015 (Table 1). The 


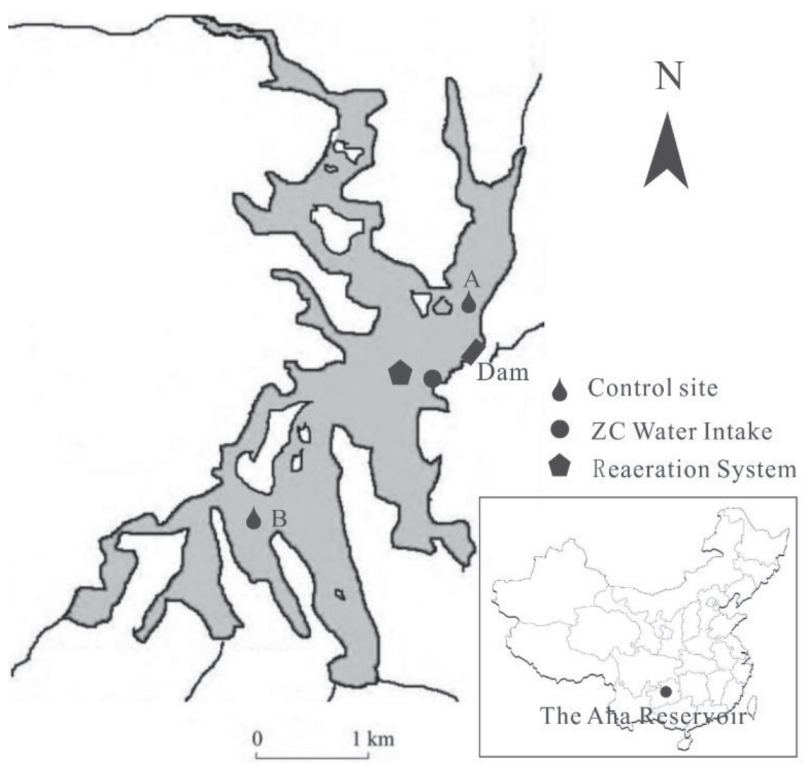

Fig. 1. Location map of the AHR reaeration area and sampling sites.

contents of TP and TN were analyzed, and the results are shown in Table 1. According to the Environmental Quality Standards for Surface Water (CEPA, 2002), the indexes, including TP and TN, of the water in the drinking water outlet area seriously exceeded the limits. The water was evolving toward Class IV based on the China National Water Quality Standard. The AHR is currently classified as a eutrophic reservoir.

\section{Hypolimnetic Oxygenation}

A reaeration system was placed $50 \mathrm{~m}$ away from the shore and $500 \mathrm{~m}$ away from the dam (Fig. 2). The average water depth was $20 \mathrm{~m}$ around the system. Pure oxygen $(94 \%)$ at a flow rate of $20 \mathrm{~m}^{3} / \mathrm{h}$ was delivered to the reaeration device via a rubber hose using a pressure swing adsorption system.
A mixture of water and gas is called plume. This could occur as gas is ejected from a device that is filled with numerous small holes. Driven by the rising bubble group, the hypoxia water in the hypolimnion keeps rising in the vertical direction with an inverse density gradient, and it stops when it reaches the maximum height of the plume rise. At this point, the plume momentum is zero. Then the oxygen-rich water drops back to the aquatic environment at an equilibrium depth. This includes water with nearly identical density to the oxygen-rich water, and it disperses to the surroundings and flows to a distant water body [36]. Small enough bubbles from this mechanism will not only affect thermal stratification, but also accelerate internal gas transfer and the gas dissolution rate [37].

\section{Results and Discussion}

\section{Reaeration Process}

The temperature gradient is an important feature of the thermocline. The significant seasonal thermal stratification of the AHR tends to occur during the summer period [38]. The stability of thermal stratification is the key to preventing benthic organism habitat destruction [39]. In this study, it was found that the diffusion process of horizontal intrusive gravity currents primarily occurred at a water depth range from 10-14 $\mathrm{m}$. The thermocline was not broken during the project application. The upper and lower waters never mixed. However, the hypolimnetic water with a lower temperature was constantly lifted by the plume mixture, leading to the temperature of the in situ water at a depth of 0-12 m decreasing significantly. This was the primary reason for the slight disturbance of water in the in situ water column. In addition, it was found that the behavior of the plume intrusion was successfully formed, which provided a basic guarantee for the restoration of an extensive area of the drinking water outlet area.

Table 1. Pollution characteristics of the upper, middle, and bottom water in the drinking water outlet area of the AHR prior to restoration.

\begin{tabular}{|c|c|c|c|c|c|c|c|c|}
\hline Sampling time & Sampling depth & $\begin{array}{c}\mathrm{TP} \\
(\mathrm{mg} / \mathrm{L})\end{array}$ & $\begin{array}{c}\mathrm{TN} \\
(\mathrm{mg} / \mathrm{L})\end{array}$ & $\begin{array}{c}\mathrm{T} \\
\left({ }^{\circ} \mathrm{C}\right)\end{array}$ & $\begin{array}{c}\mathrm{DO} \\
(\mathrm{mg} / \mathrm{L})\end{array}$ & $\begin{array}{c}\text { EC } \\
\text { (us/cm) }\end{array}$ & $\mathrm{pH}$ & $\begin{array}{c}\text { Transparency } \\
\text { (m) }\end{array}$ \\
\hline \multirow{3}{*}{ Jul. 2015} & Upper & 0.03 & 1.8 & 25.5 & 10.61 & 0.51 & 8.56 & \multirow{3}{*}{0.6} \\
\hline & Middle & 0.03 & 2.0 & 19.1 & 0.19 & 0.57 & 7.82 & \\
\hline & Bottom & 0.06 & 2.1 & 10.2 & 0.3 & 0.45 & 7.65 & \\
\hline \multirow{3}{*}{ Aug. 2015} & Upper & 0.05 & 2.3 & 25.9 & 7.28 & 0.53 & 8.35 & \multirow{3}{*}{0.8} \\
\hline & Middle & 0.06 & 2.8 & 22.1 & 0.37 & 0.6 & 7.81 & \\
\hline & Bottom & 0.07 & 3.0 & 10.7 & 0.77 & 0.46 & 7.47 & \\
\hline \multirow{3}{*}{ Sep. 2015} & Upper & 0.04 & 2.1 & 24.7 & 2.49 & 0.51 & 8.76 & \multirow{3}{*}{1.0} \\
\hline & Middle & 0.05 & 2.3 & 22.8 & 0.68 & 0.63 & 7.92 & \\
\hline & Bottom & 0.05 & 2.1 & 10.9 & 0.83 & 0.47 & 7.52 & \\
\hline
\end{tabular}




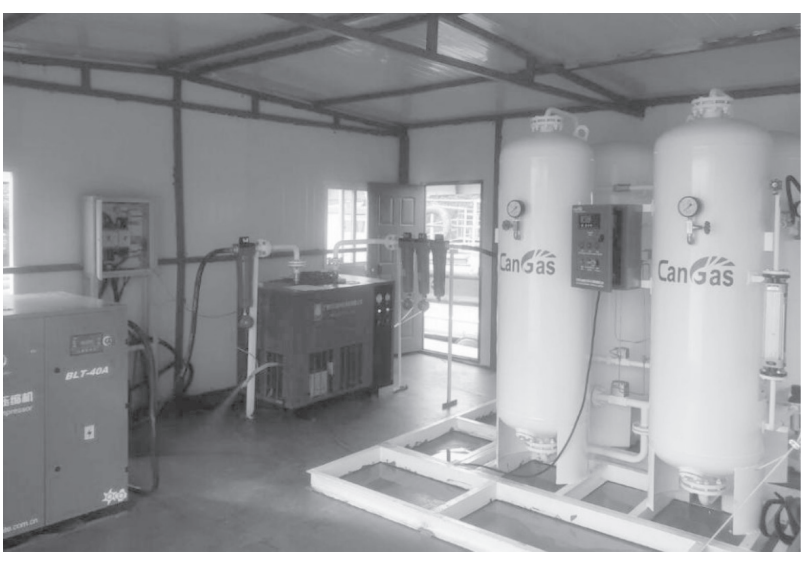

Fig. 2. Photo of the reaeration system on the platform.

The intrusion process occurred at a water depth range from 10-14 $\mathrm{m}$. The accuracy of the monitoring equipment of the intrusion flow for depth and dissolved oxygen was up to 0.001 and 0.01 , respectively. In this study, nine complete monitoring results of the intrusion flow were counted (Fig. 3). Within a radius of $150 \mathrm{~m}$, the presence of the intrusion flow was detected nearly every time at a water depth range from 11-12 m, indicating that the intrusion flow was more frequently found at the relative upper side of the intrusion layer $(10-14 \mathrm{~m})$. However, the intrusion thickness decreased with an increase in the intrusion distance. At the end of the intrusion $(250-300 \mathrm{~m})$, the intrusion thickness was less than $2 \mathrm{~m}$. During the nine monitoring processes, the presence of the intrusion flow could only be detected 1-2 times at the end of the intrusion distance. The spread of the axisymmetric intrusive gravity currents at the equilibrium depth reached a $250 \mathrm{~m}$ radius horizontally from the in situ water column. In spite of repeated attempts to monitor the gravity flow in detail (the interval in the vertical profile of the water column was $10-20 \mathrm{~cm}$ ), the presence of the gravity flow was not detected consistently. This indicates that the radius of influence of the reoxygenation intrusion flow was approximately a $250 \mathrm{~m}$ radius horizontally from the in situ water column.

\section{Water Quality Remediation Effect}

\section{Reduction of TP and TN}

Continuous water quality analyses and monitoring were conducted in the experimental zone of the ZC water intake for each month. Compared with the water quality prior to application, both $\mathrm{TP}$ and $\mathrm{TN}$ in the experimental zone were reduced. There was a significant decrease in $\mathrm{TP}$ and $\mathrm{TN}$ concentrations in the experimental zone $(0.04-0.02 \mathrm{mg} / \mathrm{L}$ and $1.9-1.7 \mathrm{mg} / \mathrm{L}$, respectively), with no significant decrease in TP and TN concentrations in the control sites. The reduction quantity of TP was nearly 50\% compared with the corresponding period. The concentration of TN at the upper, middle, and lower layers of the experimental zone were significantly lower than that prior to the application. The average reduction rates of the $\mathrm{PO}_{4}^{3-}$ concentration at the upper, middle, and lower layers of the experimental zone were $-8.5 \%, 1.9 \%$, and $-71.4 \%$. The concentration of $\mathrm{PO}_{4}^{3-}$ did not decrease significantly.

\section{Water Quality Restoration Mechanism}

In this study, it was found that during the application, the oxygen dissolution efficiency was up to $95 \%$, and most of the oxygen was dissolved into the water. However, although the dissolved oxygen in

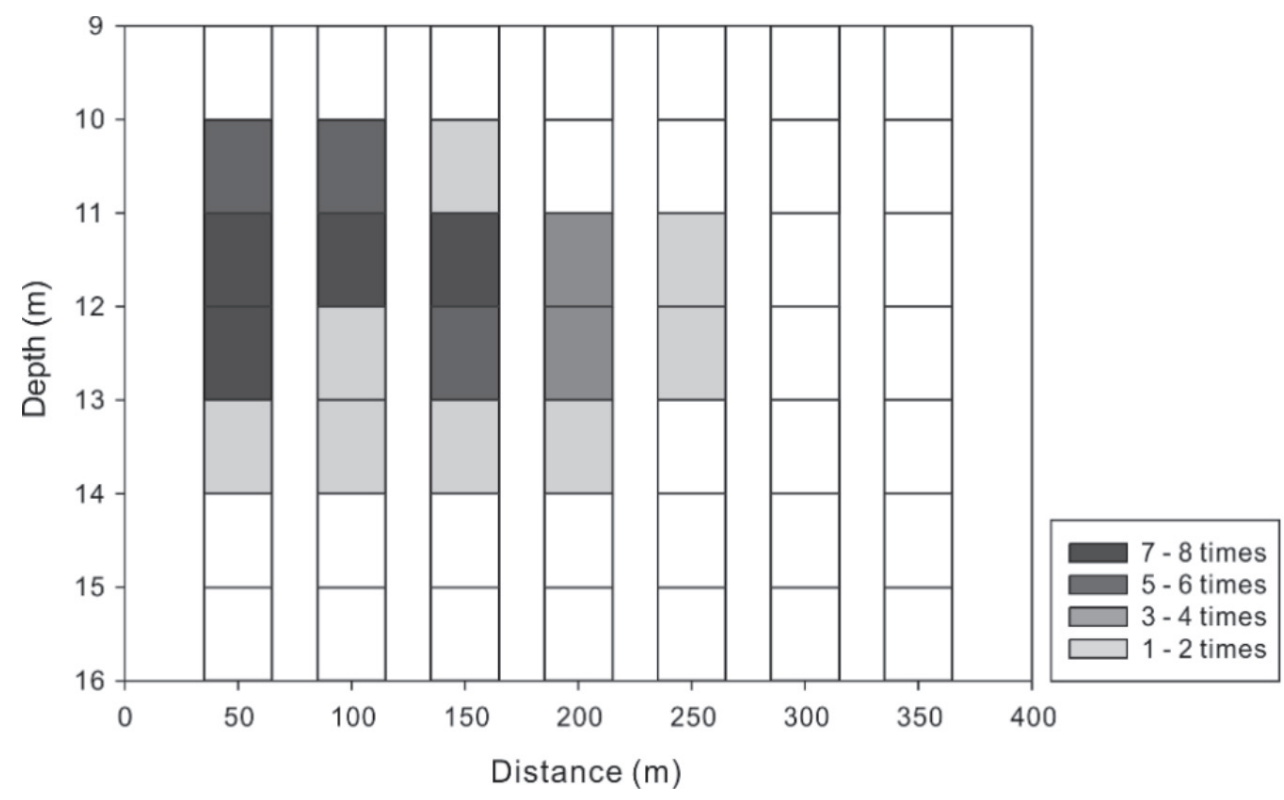

Fig. 3. Statistics of the monitoring results of the intrusion. 
the middle layer increased significantly, improvement was limited in the lower layer. The possible reason is that most of the oxygen introduced in the water was immediately consumed by organic matter and other reduced substances in the water, such as $\mathrm{Fe}, \mathrm{Mn}, \mathrm{S}^{2-}$, and $\mathrm{NH}_{4}^{+}$. In 2016, compared with 2015 from July to September, the percentage net decrease of $\mathrm{NH}_{4}^{+}$, total $\mathrm{Fe}$, and total $\mathrm{Mn}(15.5 \%, 45.5 \%$, and $48.9 \%)$ in the experimental zone supported the perspective of the macroscopic point of view.

Two mechanisms that contribute to a decrease in the concentration of TP in a eutrophic reservoir are as follows: (1) bubble plume diffusers can inhibit the release of phosphorus from sediments by increasing the dissolved oxygen in the hypolimnion. Phosphorus (especially BD-P) in sediments is more easily released under hypoxic conditions [40]. (2) The increase in dissolved oxygen in water will accelerate the precipitation of phosphorus in water [41]. In addition, the mechanism of TN concentration decrease is because the application can inhibit the release of ammonia in sediments by increasing the dissolved oxygen in the water, thus inhibiting the release of nitrogen, which is released in the form of ammonia.

\section{Influence of Evolution on the Phytoplankton}

\section{Species Composition of the Phytoplankton}

Among the various organisms present in any water body, phytoplankton that form the base of the entire food web in an aquatic ecosystem can be used a potent indicator to measure water quality for a healthy ecosystem and trophic conditions [42, 43]. Recent studies have shown that water level fluctuations have a great influence on the phytoplankton composition [44]. Phytoplankton compositional changes may greatly reflect environmental changes, such as changes in hydrodynamics mediated by water level increases [45]. Therefore, long-term monitoring of the phytoplankton evolution in the AHR was conducted while artificially controlling of the water levels. Table 2 shows the various composition types of phytoplankton species in the experimental site and control sites and the corresponding period in the AHR. The composition of phytoplankton species and cyanobacteria species changed significantly after the application. Sites A and $B$ were both regarded as control sites. The variation in phytoplankton in sites A and B were generally very similar to each other during the complete monitoring period of one year, but significantly different from that of the experimental site itself. From March to April 2016, the numbers of phytoplankton species and cyanobacteria species in both the experimental site and the control sites were not large. Hypoxia in the lower layer had occurred since May, which resulted in a rise in temperature and stratification of the water body. This led to the release of phosphorus from sediments and the deterioration of water quality $[11,46]$. Afterwards, the reservoir began to become eutrophic. The number of phytoplankton and cyanobacteria in the water was significantly higher than that during March or April. After the application, although the basic variation tendency of phytoplankton evolution over time in each representative site was similar to that before, the number of cyanobacteria species in the drinking water outlet area decreased by $33 \%-100 \%$ during the peak period of algal blooms, with no sign of an increase at all. The number of phytoplankton species in the three respective sites decreased significantly compared with that in 2016, which may have been caused by the continuous flow of water after the water quality enhancement in the drinking water outlet area. No fences were placed in the water between the experimental site and the control sites. In spite of this, the number of phytoplankton species in the ZC experimental site decreased by as much as $82.6 \%$ compared with the corresponding period prior to the application. Compared with the reduction rate of the two control sites (with A $69.9 \%$ and B $50.0 \%$ ), such a large drop indicates that the influence of the bubble plume diffusers on the phytoplankton species composition was significant.

\section{Distribution of the Dominant Phytoplankton Species}

A species with a relative abundance (proportion of a certain cell density of the algae to the total cell density) greater than $10 \%$ is considered as a dominant species

Table 2. Variation in the phytoplankton species compositions in the experimental site (ZC) and control sites (A and B) and the corresponding periods in the AHR.

\begin{tabular}{|c|c|c|c|c|c|c|c|c|c|c|c|c|c|c|c|c|}
\hline & & \multicolumn{3}{|c|}{ March } & \multicolumn{3}{|c|}{ April } & \multicolumn{3}{|c|}{ May } & \multicolumn{3}{|c|}{ June } & \multicolumn{3}{|c|}{ July } \\
\hline & & A & B & $\mathrm{ZC}$ & A & B & $\mathrm{ZC}$ & A & B & $\mathrm{ZC}$ & A & B & $\mathrm{ZC}$ & A & B & $\mathrm{ZC}$ \\
\hline \multirow{2}{*}{$\begin{array}{c}2016 \\
\text { (Before) }\end{array}$} & $\mathrm{C}$ & 0 & 3 & 2 & 1 & 1 & 1 & 3 & 3 & 2 & 2 & 3 & 3 & 3 & 3 & 4 \\
\hline & $\mathrm{P}$ & 19 & 24 & 23 & 16 & 23 & 23 & 29 & 20 & 21 & 16 & 22 & 23 & 20 & 22 & 21 \\
\hline \multirow{2}{*}{$\begin{array}{c}2017 \\
\text { (After) }\end{array}$} & $\mathrm{C}$ & 1 & 3 & 1 & 2 & 2 & 1 & 1 & 2 & 2 & 2 & 3 & 1 & 1 & 2 & 0 \\
\hline & $\mathrm{P}$ & 11 & 15 & 11 & 11 & 17 & 14 & 9 & 17 & 9 & 14 & 15 & 8 & 9 & 11 & 3 \\
\hline
\end{tabular}

$\mathrm{C}$ represents the number of cyanobacteria species, and $\mathrm{P}$ represents the number of phytoplankton species. ZC represents the experimental site in the drinking water outlet area. A and B are the control sites. 
Table 3. Dominant species each month during the sampling period from 2016 to 2017.

\begin{tabular}{|c|c|}
\hline Sampling Time & Dominant Species \\
\hline 2016/03/01 & Asterionella sp., Fragilaria sp. \\
\hline 2016/03/15 & Asterionella sp. \\
\hline $2016 / 03 / 29$ & Asterionella sp. \\
\hline 2016/04/12 & Asterionella sp. \\
\hline $2016 / 04 / 26$ & Cyclotella sp., Pseudanabaena sp., Limnothrix sp. \\
\hline $2016 / 05 / 10$ & Cyclotella sp., Pseudanabaena sp., Limnothrix sp. \\
\hline $2016 / 05 / 24$ & Cyclotella sp., Pseudanabaena sp., Limnothrix sp., Synedra sp. \\
\hline 2016/06/07 & Pseudanabaena sp. \\
\hline $2016 / 06 / 21$ & Pseudanabaena sp. \\
\hline 2016/07/05 & Pseudanabaena sp., Cyclotella sp., Synedra sp. \\
\hline 2016/07/19 & Pseudanabaena sp., Cyclotella sp., Synedra sp. \\
\hline 2016/08/02 & Pseudanabaena sp., Cyclotella sp., Synedra sp., Achnanthes sp. \\
\hline 2016/08/09 & Pseudanabaena sp., Cyclotella sp., Synedra sp., Achnanthes sp. \\
\hline 2016/08/16 & Pseudanabaena sp., Cyclotella sp., Synedra sp., Achnanthes sp. \\
\hline $2016 / 08 / 23$ & Pseudanabaena sp., Cyclotella sp., Achnanthes sp. \\
\hline $2016 / 08 / 30$ & Pseudanabaena sp., Cyclotella sp., Synedra sp., Achnanthes sp. \\
\hline 2016/09/06 & Pseudanabaena sp., Cyclotella sp., Synedra sp., Achnanthes sp. \\
\hline 2016/09/13 & Pseudanabaena sp., Merismopedia sp., Cyclotella sp., Synedra sp., Achnanthes sp. \\
\hline $2016 / 09 / 20$ & Pseudanabaena sp., Merismopedia sp., Cyclotella sp., Achnanthes sp. \\
\hline $2016 / 09 / 27$ & Pseudanabaena sp., Merismopedia sp., Cyclotella sp., Synedra sp., Achnanthes sp. \\
\hline 2016/10/11 & Pseudanabaena sp., Cyclotella sp., Synedra sp., Achnanthes sp. \\
\hline $2016 / 11 / 15$ & Pseudanabaena sp., Cyclotella sp., Synedra sp., Melosira granulata \\
\hline $2016 / 12 / 20$ & Cyclotella sp., Synedra sp., Melosira granulata \\
\hline 2017/01/10 & Cyclotella sp. \\
\hline 2017/02/17 & Cyclotella sp., Synedra sp. \\
\hline 2017/03/08 & Synedra sp., Peridiniopsis Lemmermann \\
\hline $2017 / 03 / 23$ & Synedra sp., Peridiniopsis Lemmermann \\
\hline 2017/04/07 & Cyclotella sp., Synedra sp. \\
\hline 2017/04/19 & Cyclotella sp., Synedra sp. \\
\hline 2017/05/11 & Cyclotella sp., Synedra sp. \\
\hline $2017 / 05 / 24$ & Cyclotella sp., Synedra sp. \\
\hline 2017/06/07 & Pseudanabaena sp., Cyclotella sp., Synedra sp. \\
\hline 2017/06/19 & Pseudanabaena sp., Cyclotella sp., Synedra sp. \\
\hline 2017/07/11 & Cyclotella sp., Synedra sp. \\
\hline $2017 / 07 / 25$ & Pseudanabaena sp., Cyclotella sp., Synedra sp. \\
\hline
\end{tabular}

[47]. During the monitoring period, the dominant species primarily included Asterionella sp., Fragilaria sp., Pseudanabaena sp., Cyclotella sp., Synedra sp., Achnanthes sp., and Limnothrix sp. (Table 3). The species and number of dominant species are important characteristics related to the stability of a community structure [48]. There were only one or two dominant species on March $1^{\text {st }}$, March $15^{\text {th }}$, March $29^{\text {th }}$, April $12^{\text {th }}$, June $7^{\text {th }}$, and June $21^{\text {st }}$ during the six sample collection times. The number of dominant species was 
significantly different from that of other species. The community structure was relatively simple, indicating that the risk of algal bloom outbreaks was high [33]. In other months, the risk of blooms decreased as the number of dominant species of phytoplankton increased. By comparing the characteristics of dominant species of phytoplankton in 2016 with those of 2017, the Pseudanabaena, which belongs to the Cyanobacteria, was superior in quantitative terms since May 2016 in the AHR. The Cyanobacteria abundance reached a peak in July 2016. In 2017, the Cyanobacteria no longer dominated, instead Bacillariophyta dominated, which is primarily composed of Cyclotella and Synedra. Pseudanabaena, a common toxic algal species that has occurred in algal blooms in the AHR in previous years, displayed a decrease in biomass. This indicated that the phytoplankton structure in this area has changed significantly [49, 50], and this had a positive impact on the control of cyanobacterial blooms in the AHR.

The frequent occurrence of toxin-producing harmful cyanobacterial blooms poses a serious threat to environmental and human health [51, 52]. Microcystins (MCs) are considered to be the most commonly detected and widely distributed toxins compared with other cyanotoxins, such as cylindrospermopsin and anatoxin [53]. To date, more than 100 structural variants of MCs have been identified from cyanobacterial blooms and cultures worldwide. Among them, microcystin-LR (MC-LR) and microcystin-RR (MC-RR) are the two most commonly reported in natural waters [54]. The concentrations of MC-LR, MC-RR, and total MC of the experimental site and control sites in the eutrophic reservoir were monitored from March 2016 to March 2017. In general, MC degrade faster under the condition of sunny days and microbial action [55]. The variation tendency over time of the total quantity of $\mathrm{MC}$ in the surface layer, middle layer, and lower layer of the three representative sites in this study (in terms of total quantity of MC-LR and MC-RR) were similar in mass. The variation process included three stages. The first stage was from March $15^{\text {th }}, 2016$ to May 10 $0^{\text {th }}, 2016$, and the total concentrations of $\mathrm{MC}$ in the upper layers at the monitoring sites reached a maximum of $3.39 \mu \mathrm{g} / \mathrm{L}$. However, according to the Standards for Drinking Water Quality (WHO), the MC-LR did not exceed the limit of $1.0 \mu \mathrm{g} / \mathrm{L}$. The second stage was from May $24^{\text {th }}, 2016$ to June $19^{\text {th }}, 2016$. At this stage, the total concentrations of $\mathrm{MC}$ in the upper and lower layers were similar among the three monitoring sites. In addition, the total concentrations of $\mathrm{MC}$ in the middle layers reached a peak of $0.49 \mu \mathrm{g} / \mathrm{L}$. This phenomenon occurred due to the death of toxin-producing algae. The toxin-producing algae died and began to precipitate, but had not yet arrived at the bottom of the reservoir at this stage. With the death of toxin-producing algae, a large amount of $\mathrm{MC}$ was released [56]. Hence, in the last stage and the last phase of algal growth, the total concentrations of $\mathrm{MC}$ in the upper layers at the three monitoring sites approached zero, while the total concentrations of MC in the middle and lower layers were similar to each other. The reason is that larger algae began apoptosis in autumn and substantial corpses of toxin-producing algae begin to precipitate. This was accompanied by the release of a large number of $\mathrm{MC}$.

During the monitoring period, the concentrations of the two kinds of algal toxins was generally low, but the concentration of MC-RR was higher than that of MCLR. MC-LR did not exceed the limits of the Standards for Drinking Water Quality. From the perspective of seasonal changes, March is the extinction period of $\mathrm{MC}$, and the concentrations of both MC-RR and MC-LR was very low. April and May are periods with frequent outbreaks of algal toxins in the eutrophic reservoir, and the detection rate for $\mathrm{MC}$ was very high. The total concentration of $\mathrm{MC}$ reached the maximum at this time. The periodic outbreak of algal toxins from June to August was very obvious, with small peaks occurring irregularly, but none exceeded the amount in May. The concentration of $\mathrm{MC}$ began to decline in May and was nearly zero by late August. The concentrations of MCLR and MC-RR at the three monitoring sites showed a general trend that included explosion, slow decline, and an approach to zero from March to October in 2016. Compared with MC-RR, the concentration variation of MC-LR at the three monitoring sites tended to be flat, hovering near $0.1 \mu \mathrm{g} / \mathrm{L}$, far lower than the guidance value of $1 \mu \mathrm{g} / \mathrm{L}$. The variation tendency of the concentration of total MC was similar to that of MC-LR and MC-RR during the entire period. The variation tendency of the time of concentrations of total MC in the surface layer, middle layer, and bottom layer at the three monitoring sites in the eutrophic reservoir were similar to each other. The effect of the application on the MC variation in the water outlet area and even the eutrophic reservoir was minimal throughout the entire monitoring period, which indicated that toxin production is regulated by a complex set of environmental conditions.

\section{Conclusions}

In this study, hypolimnetic oxygenation was applied to restore the water quality environment of a drinking water outlet area in the AHR, a eutrophic reservoir in southwest China. The conclusions are as follows.

1) The application of hypolimnetic oxygenation can not only significantly reduce the concentration of TP, $\mathrm{TN}, \mathrm{NH}_{4}^{+}$, total $\mathrm{Fe}$, and total $\mathrm{Mn}$ in the drinking water outlet area of the AHR (a typical eutrophic reservoir), but also effectively reduce the abundance of algae, especially the relative abundance of cyanobacteria. The application of bubble plume diffusers has a great influence on the evolution of phytoplankton in such a eutrophic reservoir, but little effect on the variation in MC. During the entire application period, no significant algal blooms occurred at the ZC drinking water outlet area and its adjacent water, which ensured water quality near 
the water outlet and the safety of the subsequent water supply.

2) The behavior of the plume intrusion was successful in the AHR, indicating that this technology is feasible for a sub-deep water system. This study provides important technical support and a case reference for reoxygenation for an extensive water area.

\section{Acknowledgments}

This work was financially supported by the Research Project for Advanced Talents of Guizhou University of Finance and Economics 2018. (No. 2018YJ39).

\section{Conflict of Interest}

The authors declare no conflict of interest.

\section{References}

1. VIN ON-LEITE B., CASENAVE C. Modelling eutrophication in lake ecosystems: A review. Sci. Total Environ. 651, 2985, 2019.

2. LIU B., MCLEAN C.E., LONG D.T., STEINMAN A.D., STEVENSON R.J. Eutrophication and recovery of a Lake inferred from sedimentary diatoms originating from different habitats. Sci. Total Environ. 628, 1352, 2018.

3. SINHA E., MICHALAK A., BALAJI V. Eutrophication will increase during the 21st century as a result of precipitation changes. Science. 357 (6349), 405, 2017.

4. VAN HELMOND N.A., ROBERTSON E.K., CONLEY D.J., HERMANS M., HUMBORG C., KUBENECK L.J., LENSTRA W.K., SLOMP C.P. Efficient removal of phosphorus and nitrogen in sediments of the eutrophic Stockholm Archipelago, Baltic Sea. Biogeosci. Disc. 1, 2019.

5. LONG S.X., YANG Y., XIA P.H., CHEN C., LIU Z.W., MA J.R., DONG X., HE T.R., YUN G. Accumulation of metals in zooplankton from karst plateau reservoirs with different eutrophic status in Guizhou Province, PR China. Crustaceana. 89 (5), 537, 2016.

6. CHEN J.A., YANG H.Q., ZHANG D.D., XU D., LUO J., WANG J.F. A particular river-whiting phenomenon caused by discharge of hypolimnetic water from a stratified reservoir. PLoS One. 10 (9), 1, 2015.

7. LE C., ZHA Y., LI Y., SUN D., LU H., YIN B. Eutrophication of lake waters in China: cost, causes, and control. Environ. Manage. 45 (4), 662, 2010.

8. LIU W., QIU R. Water eutrophication in China and the combating strategies. J. Chem. Technol. Biotechnol. 82 (9), 781, 2007.

9. WANG J., CHEN J., JIN Z., GUO J., YANG H., ZENG Y., LIU Y. Simultaneous removal of phosphate and ammonium nitrogen from agricultural runoff by amending soil in lakeside zone of Karst area, Southern China. Agric., Ecosyst. Environ. 289, 106745, 2020.

10. CHEN Q., CHEN J., WANG J., GUO J., JIN Z., YU P., MA $Z$. In situ, high-resolution evidence of phosphorus release from sediments controlled by the reductive dissolution of iron-bound phosphorus in a deep reservoir, southwestern China. Sci. Total Environ. 666, 39, 2019.

11. YANG H., HE K., LU D., WANG J., XU D., JIN Z., YANG M., CHEN J. Removal of phosphate by aluminummodified clay in a heavily polluted lake, Southwest China: Effectiveness and ecological risks. Sci. Total Environ. 705, 135850, 2020.

12. WANG J., CHEN J., CHEN Q., YANG H., ZENG Y., YU P., JIN Z. Assessment on the effects of aluminum-modified clay in inactivating internal phosphorus in deep eutrophic reservoirs. Chemosphere. 215, 657, 2019.

13. HE T., ZHU Y., YIN D., LUO G., AN Y., YAN H., QIAN $\mathrm{X}$. The impact of acid mine drainage on the methylmercury cycling at the sediment-water interface in Aha Reservoir, Guizhou, China. Environmental Science and Pollution Research. 22 (7), 5124, 2015.

14. MEHNER T., DIEKMANN M., GONSIORCZYK T., KASPRZAK P., KOSCHEL R., KRIENITZ L., RUMPF M., SCHULZ M., WAUER G. Rapid recovery from eutrophication of a stratified lake by disruption of internal nutrient load. Ecosystems. 11 (7), 1142, 2008.

15. SHAH N.S., KHAN J.A., SAYED M., KHAN Z.U. H., IQBAL J., IMRAN M., MURTAZA B., ZAKIR A., POLYCHRONOPOULOU K. Nano zerovalent zinc catalyzed peroxymonosulfate based advanced oxidation technologies for treatment of chlorpyrifos in aqueous solution: A semi-pilot scale study. Journal of Cleaner Production. 246, 119032, 2020.

16. KHAN J.A., SAYED M., SHAH N.S., KHAN S., ZHANG Y., BOCZKAJ G., KHAN H.M., DIONYSIOU D.D. Synthesis of eosin modified $\mathrm{TiO}_{2}$ film with co-exposed $\{001\}$ and $\{101\}$ facets for photocatalytic degradation of para-aminobenzoic acid and solar $\mathrm{H} 2$ production. Applied Catalysis B: Environmental. 265, 118557, 2020.

17. IQBAL J., SHAH N.S., SAYED M., KHAN J.A., MUHAMMAD N., KHAN Z.U.H., NASEEM M., HOWARI F.M., NAZZAL Y., NIAZI N.K. Synthesis of Nitrogen-doped Ceria Nanoparticles in Deep Eutectic Solvent for the Degradation of Sulfamethaxazole under Solar Irradiation and Additional Antibacterial Activities. Chem. Eng. J. 394, 124869, 2020.

18. GUL I., SAYED M., SHAH N.S., KHAN J.A., POLYCHRONOPOULOU K., IQBAL J., REHMAN F. Solar light responsive bismuth doped titania with $\mathrm{Ti}^{3+}$ for efficient photocatalytic degradation of flumequine: Synergistic role of peroxymonosulfate. Chem. Eng. J. 384, 123255,2020

19. SAYED M., GUL M., SHAH N.S., KHAN J.A., KHAN Z.U.H., REHMAN F., KHAN A.R., RAUF S., ARANDIYAN H., YANG C.P. In-situ dual applications of ionic liquid coated $\mathrm{Co}^{2+}$ and $\mathrm{Fe}^{3+}$ co-doped $\mathrm{TiO}_{2}$ : superior photocatalytic degradation of ofloxacin at pilot scale level and enhanced peroxidase like activity for calorimetric biosensing. J. Mol. Liq. 282, 275, 2019.

20. SAYED M., AROOJ A., SHAH N.S., KHAN J.A., SHAH L.A., REHMAN F., ARANDIYAN H., KHAN A.M., KHAN A.R. Narrowing the band gap of $\mathrm{TiO}_{2}$ by co-doping with $\mathrm{Mn}^{2+}$ and $\mathrm{Co}^{2+}$ for efficient photocatalytic degradation of enoxacin and its additional peroxidase like activity: a mechanistic approach. J. Mol. Liq. 272, 403, 2018.

21. BEUTEL M.W., HORNE A.J. A review of the effects of hypolimnetic oxygenation on lake and reservoir water quality. Lake Reserv Manage. 15 (4), 285, 1999.

22. VICKIE L., SINGLETON JOHN C.L. Designing hypolimnetic aeration and oxygenation systems-a review. Environ. Sci. Technol. 40 (24), 7512, 2006. 
23. PREECE E.P., MOORE B.C., SKINNER M.M., CHILD A., DENT S. A review of the biological and chemical effects of hypolimnetic oxygenation. Lake Reserv Manage. 35 (3), 229, 2019.

24. WUEST A., NORMAN H.B. Bubble plume modeling for restoration. Water Resour. Res. 28 (12), 3235, 1992.

25. MCGINNIS D.F., LORKE A., WUEST A., STOCKLI A., LITTLE J.C. Interaction between a bubble plume and the near field in a stratified lake. Water Resour. Res. 40 (10), $1,2004$.

26. ZHANG F., HU C., SHUM C., LIANG S., LEE J. Satellite remote sensing of drinking water intakes in Lake Erie for cyanobacteria population using two MODIS-based indicators as a potential tool for toxin tracking. Frontiers in Marine Science. 4, 124, 2017.

27. YANG L., HE J., LIU Y., WANG J., JIANG L., WANG G. Characteristics of change in water quality along reclaimed water intake area of the Chaobai River in Beijing, China. Journal of environmental sciences. 50, 93, 2016.

28. MICHELl F., ETTEMA R., MUSTE M. Case study: Sediment control at water intake for large thermal-power station on a small river. J. Hyg. Eng. 132 (5), 440, 2006.

29. PIONTEK M., CZYŻEWSKA W. Efficiency of Drinking Water Treatment Processes. Removal of Phytoplankton with Special Consideration for Cyanobacteria and Improving Physical and Chemical Parameters. Polish Journal of Environmental Studies. 21 (6), 2012.

30. EUN H., SEOK S. A hydrodynamic modeling study to determine the optimum water intake location in Lake Paldang, Korea. Journal of the American Water Resources Association. 41 (6), 1315, 2005.

31. ANDERSON D.M. Approaches to monitoring, control and management of harmful algal blooms (HABs). Ocean Coast. Manage. 52 (7), 342, 2009.

32. TARANU Z.E., GREGORY-EAVES I., STEELE R.J., BEAULIEU M., LEGENDRE P. Predicting microcystin concentrations in lakes and reservoirs at a continental scale: A new framework for modelling an important health risk factor. Global Ecol. Biogeogr. 26 (6), 625, 2017.

33. WATSON S.B., MILLER C., ARHONDITSIS G., BOYER G.L., CARMICHAEL W., CHARLTON M.N., CONFESOR R., DEPEW D.C., H K T. O., LUDSIN S.A. The re-eutrophication of Lake Erie: Harmful algal blooms and hypoxia. Harmful Algae. 56 (2), 44, 2016.

34. ALADDIN L. M., AZIZ F. Response of Algae to Heavy Metal Removing with Particular Reference to $\mathrm{pH}$. Polish Journal of Environmental Studies. 29 (3), 2041, 2020.

35. SOJKA M., SIEPAK M., JASKUŁA J., WICHERDYSARZ J. Heavy Metal Transport in a River-Reservoir System: a Case Study from Central Poland. Polish Journal of Environmental Studies. 27 (4), 2018.

36. MULLER B., BRYANT L.D., MATZINGER A., WUEST A. Hypolimnetic oxygen depletion in eutrophic lakes. Environ. Sci. Technol. 46 (18), 9964, 2012.

37. FRAGA B., STOESSER T. Influence of bubble size, diffuser width, and flow rate on the integral behavior of bubble plumes. J. Geophys. Res. 121 (1), 1, 2016.

38. SONG L.T., LIU C.Q., WANG Z.L., ZHU X.K., TENG Y.G., LIANG L.L., TANG S.H., LI J. Iron isotope fractionation during biogeochemical cycle: Information from suspended particulate matter (SPM) in Aha Lake and its tributaries, Guizhou, China. Chem. Geol. 280 (1), 170, 2011.

39. WANG J., CHEN J., DING S., GUO J., CHRISTOPHER D., DAI Z., YANG H. Effects of seasonal hypoxia on the release of phosphorus from sediments in deep-water ecosystem: A case study in Hongfeng Reservoir, Southwest China. Environ. Pollut. 219, 858, 2016.

40. HUPFER M., LEWANDOWSKI J. Oxygen controls the phosphorus release from lake sediments-a long lasting paradigm in limnology. Int. Rev. Hydrobiol. 93 (4-5), 415, 2008.

41. BORMANS M., MARŠ LEK B., JANČULA D. Controlling internal phosphorus loading in lakes by physical methods to reduce cyanobacterial blooms: a review. Aquat. Ecol. 50 (3), 407, 2016.

42. MISHRA P., GARG V., DUTT K. Seasonal dynamics of phytoplankton population and water quality in Bidoli reservoir. Environ. Monit. Assess. 191 (3), 130, 2019.

43. THAKUR R.K., JINDAL R., SINGH U.B., AHLUWALIA A.S. Plankton diversity and water quality assessment of three freshwater lakes of Mandi (Himachal Pradesh, India) with special reference to planktonic indicators. Environ. Monit. Assess. 185 (10), 8355, 2013.

44. LI Q., XIAO J., OU T., HAN M., WANG J., CHEN J., LI Y., SALMASO N. Impact of water level fluctuations on the development of phytoplankton in a large subtropical reservoir: implications for the management of cyanobacteria. Environmental Science and Pollution Research. 25 (2), 1306-1318, 2017.

45. PAN Y., GUO S., LI Y., YIN W., QI P., SHI J., HU L., LI B., BI S., ZHU J. Effects of Water Level Increase on Phytoplankton Assemblages in a Drinking Water Reservoir. Water. 10 (3), 256, 2018.

46. CUI Y., ZHU G., LI H., LUO L., CHENG X., JIN Y., TROLLE D. Modeling the response of phytoplankton to reduced external nutrient load in a subtropical Chinese reservoir using DYRESM-CAEDYM. Lake Reserv Manage. 32 (2), 146, 2016.

47. BORICS G., T THM R SZ B., V RB R G., GRIGORSZKY I., CZ BELY A., G RG NYI J. Functional phytoplankton distribution in hypertrophic systems across water body size. Hydrobiologia. 764 (1), 81, 2016.

48. ZHANG M., YU Y., YANG Z., KONG F. Deterministic diversity changes in freshwater phytoplankton in the Yunnan-Guizhou Plateau lakes in China. Ecol. Indicators. 63, 273, 2016.

49. GAO J., ZHU J., WANG M., DONG W. Dominance and Growth Factors of Pseudanabaena sp. in Drinking Water Source Reservoirs, Southern China. Sustainability. 10 (11), 3936, 2018.

50. BUKOWSKA A., KALINSKI T., KOPER M., KOSTRZEWSKA-SZLAKOWSKA I., KWIATOWSKI J., MAZUR-MARZEC H., JASSER I. Predicting blooms of toxic cyanobacteria in eutrophic lakes with diverse cyanobacterial communities. Sci. Rep. 7 (1), 8342, 2017.

51. CUNHA D.G.F., DODDS W.K., LOISELLE S.A. Factors related to water quality and thresholds for microcystin concentrations in subtropical Brazilian reservoirs. Inland Waters. 8 (3), 368, 2018.

52. MAJOR Y., KIFLE D., SPOOF L., MERILUOTO J. Cyanobacteria and microcystins in Koka reservoir (Ethiopia). Environmental Science and Pollution Research. 25 (27), 26861, 2018.

53. PHAM T.-L., DAO T.-S., TRAN N.-D., NIMPTSCH J., WIEGAND C., MOTOO U. Influence of environmental factors on cyanobacterial biomass and microcystin concentration in the Dau Tieng Reservoir, a tropical eutrophic water body in Vietnam. Annales de Limnologie - International Journal of Limnology. 53, 89, 2017.

54. PUDDICK J., PRINSEP M.R., WOOD S.A., KAUFONONGA S.A., CARY S.C., HAMILTON D.P. 
High levels of structural diversity observed in microcystins from Microcystis CAWBG11 and characterization of six new microcystin congeners. Mar. Drugs. 12 (11), 5372, 2014.

55. ZHOU J., QIN B., HAN X., ZHU L. Turbulence increases the risk of microcystin exposure in a eutrophic lake (Lake
Taihu) during cyanobacterial bloom periods. Harmful Algae. 55, 213, 2016.

56. GAGET V., HUMPAGE A.R., HUANG Q., MONIS P., BROOKES J.D. Benthic cyanobacteria: A source of cylindrospermopsin and microcystin in Australian drinking water reservoirs. Water Res. 124, 454, 2017. 